\title{
THE "AUTOBIOGRAPHY” OF NIKEPHOROS BLEMMYDES. ON THE ISSUE OF RELATIONS BETWEEN MONASTICISM AND SCHOLARSHIP IN BYZANTIUM
}

The relations between monasticism and scholarship in Byzantium are usually characterized as being in conflict. Alexander Kazhdan noted that Byzantine monasteries, as opposed to Western ones, did not come to be "centers of cultural heritage preservation" and in the majority of cases rather took a hostile stance towards antique learning ${ }^{1}$ - which in fact formed the basis for all medieval science. Preservation of intellectual wealth in Byzantium used to be a worldly matter.

On the whole, Byzantium knew two kinds of "love of wisdom," that is, two kinds of philosophy, and, in accordance with them, two kinds of scholarship and science. The first kind - the "inner," that is, church philosophy - denoted theology, ascetics, Christian ethics and morality, and sometimes also a virtuous monastic way of life in general. The second kind - the "outer," that is, secular philosophy - applied to the septem artes liberales: grammar, logic, rhetoric, arithmetic, geometry, music, and astronomy. ${ }^{2}$ The teaching of the Seven Liberal Arts, based for the most part on achievements of ancient scholarship, formed the cornerstone of Byzantine education through all its history. Furthermore, the scholarly heritage of Antiquity always attracted the attention of Byzantine intellectuals. Some personalities even won the name of "Christian humanists" for their striving to combine Christian ideals with those of ancient learning.

(1) А. П. КАЖдАН, Книга и писатель в Византии, Москва, 1973, с. 136.

(2) On the two kinds of philosophy in Byzantium see D. J. O'MearA, "Philosophy," in Oxford Dictionary of Byzantium, ed. by A. KazHDan, New York, Oxford, 1991, pp. 1658-1661, here 1658-1659; H. Hunger, Die hochsprachliche profane Literatur der Byzantiner, München, 1978, S. 7-9. 
Still, although the Orthodox Church in general reconciled itself with the usage of pagan learning for educational purposes and in most cases closed its eyes to the intellectuals' great interest in antique literature and science, Byzantine monasticism, being as it was the most radical and conservative wing of the Church, disapproved of the ideas called nowadays "Christian humanism." ${ }^{3}$ Certainly, some of those Christian humanists were themselves monks (for example, the well-known Michael Psellos or Patriarch Gregory of Cyprus), but their monasticism was either nominal (as in the case of Psellos) or rather an exception (as in the case of Joseph Rhakendytes). ${ }^{4}$

Byzantine monasticism is thus characterized as a community which thought a complete renunciation of the "outer" learning to be possible. Even theology, in many respects having its foundation in the Aristotelian-Platonic philosophical tradition, could do, as the rigorists tended to believe, without any studies of pagan writings - since all the necessary borrowings had already been made by the Church Fathers.

Against such a background the figure of Nikephoros Blemmydes, a thirteenth century Byzantine writer and scholar, provokes reflection. On the one hand, Blemmydes definitely was not a "nominal" monk and what is more, he was not a "black sheep" either, as he was widely considered a role model of proper monasticism. On the other hand, his keen engagement in secular disciplines cannot be questioned. Under these circumstances, a study of Blemmydes' views on combining monasticism and scholarly activities appears rather attractive, and exactly for that reason this author has decided to analyze the so-called Autobiography of the writer. ${ }^{5}$

(3) See O'Meara," Philosophy," p. 1661; Hunger, Die hochsprachliche profane Literatur, S. 9, 50-51.

(4) On Rhakendytes' position see S. Mergial, L'enseignement et les lettrés pendant l'époque des Paléologues (1261-1453), Athens, 1996, pp. 85-86, with further bibliography.

(5) Two editions of this work exist: Nicephori Blemmydae Curriculum vitae et carmina nunc primum edita, ed. A. HeIsenberg, Leipzig, 1896, and Nicephori Blemmydae Autobiographia sive Curriculum Vitae necnon Epistula universalior, ed. J. A. Munitiz (CCSG, 13), Turnhout, Leuven, 1984. 
Some general information about Nikephorus Blemmydes (1197/98$1271 / 73)^{6}$ should be given. ${ }^{7}$ He was a zealous ascetic, eminent theologian and - regarding the epoch he lived in - an outstanding scholar. His merits in all the spheres mentioned were highly appreciated both by contemporaries (George Akropolites, Theodore II Laskaris, George Pachymeres) and succeeding generations (Nikephoros Gregoras). ${ }^{8}$ As has already been mentioned, Blemmydes is known as an original theologian, who played a significant role in the Greek-Latin theological polemics of the thirteenth century, ${ }^{9}$ and as a praised ascetic. He was an author of numerous ascetical and religious works. ${ }^{10}$ At the same time, writings left by Blemmydes, as well as evidence of independent sources, point to his wide knowledge and versatile interests. His erudition, as far as natural sciences are concerned, was clearly above the average level of his time. ${ }^{11}$ Judging by the writings preserved, his scholarly studies included, in addition to theology, medicine, geography, astronomy, physics and alchemy. Blemmydes also won his fame as a teacher, among others, at a monastery which he himself founded. ${ }^{12}$ In this monastery Blemmydes organized a school, in which he himself

(6) E. Trapp, C. Gastgeber, Hrsg., Prosopographisches Lexicon der Palaiologenzeit, Wien, 1991, S. 2897.

(7) Thorough information on Blemmydes' life and activities can be found in a commented translation of his Autobiography: Nikephoros Blemmydes, A Partial Account, introd., transl., notes by J. A. Munitiz (Spicilegium Sacrum Lovaniense, 48), Leuven, 1988, pp. 14-28.

(8) See an analysis of sources mentioning Blemmydes, as well as references to the respective publications, in Munitiz, Nikephoros Blemmydes, pp. 29-31.

(9) Г. И. БЕНевич, “Никифор Влеммид, Григорий Кипрский и др. Вопрос об исхождении Святого Духа," in Антология восточно-христианской богословской мысли. Ортодоксия и гетеродоксия, ред. Г. И. Беневич, Д. С. БИрюков, т. 2 (Smaragdos Philocalias; Византийская философия, 5), Москва, Санкт-Петербург, 2009, с. 426-436.

(10) For the lists of preserved works by Blemmydes, see А. Г. Дунаев, “Поздневизантийский исихазм и учение св. Григория Паламы," in Исихазм: аннотированная библиография, ред. С. С. Хоружий, Москва, 2004, 6, № 214-278, c. 300-496 (324-330); Trapp, GAstgeBer, Prosopographisches Lexicon, S. 2897.

(11) Hunger, Die hochsprachliche profane Literatur, S. 36.

(12) O’Meara," Philosophy," p. 296. 
lectured on both secular and church subjects. Thanks to his manuals on Aristotle's Logic and Physics, he was well known throughout Europe. ${ }^{13}$

Already distinguished as an outstanding Christian zealot, Blemmydes did not give up his studies of secular subjects. It can be said for sure that the extant scientific writings by Blemmydes were written after he had taken monastic vows (this was when he was about thirtysix, that is, already at a mature age $\left.{ }^{14}\right) \cdot{ }^{15}$

The main source of information about the life and personality of Blemmydes, apart from certain independent sources and the written legacy of the writer, is his own work - the so-called Partial Account, better known as his Autobiography. Studying this writing in the abovedescribed context, one may pose the following questions:

a) What was Blemmydes' view on combining a monastic way of life with scholarly studies? Did he consider them contradictory?

b) What was Blemmydes' perception of secular studies? What were the reasons for his life-long engagement in them?

c) Was Blemmydes a representative of a certain trend in Byzantine monasticism or rather a unique case not reflecting any general tendencies?

In the present article we shall try to answer these three questions.

First several remarks on the work as a whole should be made. The Autobiography of Nikephoros Blemmydes is a writing containing two parts or two books. The first book was finished in May, 1264, the second - in April, $1265 .{ }^{16}$ It is likely that the second volume underwent some revision in $1267 .{ }^{17}$ The author gave no title to his work. Two complete copies of the Autobiography exist and one of them is entitled, "Nt-

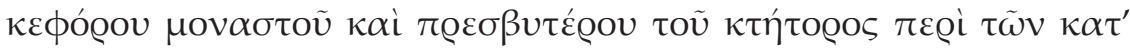

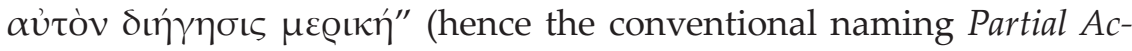
$\left.\operatorname{count} t^{18}\right)$. The title originated from the scribe; the second copy of the work has no title.

(13) Hunger, Die hochsprachliche profane Literatur, S. 36.

(14) Nikephoros Blemmydes, A Partial Account, p. 18.

(15) Trapp, Gastgeber, Prosopographisches Lexicon, S. 2897.

(16) Dating is based on the lemma of one of the two complete copies preserved (see Nicephori Blemmydae Autobiographia, pp. XI, XIII, 3, 47).

(17) Nikephoros Blemmydes, A Partial Account, p. 28.

(18) There are some further possibilities of translation and there is by now no general agreement on this issue. We follow here the variant used by Munitiz so as to avoid ambiguities. Cf. G. Misch, Geschichte der Autobiographie, B. 3.2, 
In the Autobiography Blemmydes addressed the monks of the monastery which he had founded and whose leader he was, that is, his disciples. The writer, who had been living in the so-called Nicaean Empire for most of his life, paid little attention to historical and political events: the capture of Constantinople by the Crusaders in 1204, which he witnessed as a child, and the city's return to Byzantine authority in 1261 are mentioned in a passing manner. The work is above all sermonlike and religious. At the beginning Blemmydes set for himself the task of describing the events of his life so as to praise God for all His favors and support in times of sorrow, as well as to edify and strengthen his brethren in love and striving toward God (I, 7). ${ }^{19}$ The writer started his narration telling about his education (I, 2-10). After that came the story of his Church career (I, 11-34) and the monastic period of his life (I, 74-89). Blemmydes paid special attention to the conflict and break between him and Theodore Laskaris (I, 74-89), his former disciple and friend - both the conflict and the break took place after the ascension of Theodore to the Nicaean throne. The first book of the Partial Account also has an edifying conclusion (I, 90).

In the second book from the very beginning Blemmydes set out to amplify his work with some significant information, which could not have been included in the first book for reasons of space (II, 1-2). The author said that he would mention for the second time only those events that one simply could not avoid mentioning, but he intended to refer to them briefly. He provided additional facts concerning his childhood and youth (II, 3-7), and told about his sojourn on the island of Rhodes (II, 20-24), as well as about the construction of his monastery (II, 45-49) (both episods are related for the first time). He also added a description of some events which took place after the seizure of power by Michael VIII Palaiologos (II, 79-85). The second volume also contains a description of four different discussions in which Blemmydes took part: a demonstrative exam in logic, during which Blemmydes disputed with his teacher Dimitrios Karykes at the Emperor's Court (II, 8-16); two discussions with the Latins (II, 25-40, 50-60) and one discussion with the Cilicians (that is, the Armenian Monophysites) (II, 61-66). In the second book Blemmydes also recounted the nega-

Frankfurt, 1962, S. 831 ("Sondergeschichte"); M. Hinterberger, Autobiographische Traditionen in Byzanz (WBS, 22), Wien, 1999, S. 361 ("Genaue Erzählung"). The variant suggested in the last work seems to us the most appropriate.

(19) Hereafter references to the edition by Munitiz, denoting the book and the number of the chapter. Division into chapters was made by the editor. 
tive consequences that aroused from his encomium on St. John the Theologian, and briefly conveyed the contents of his apology on the matter, initially expounded upon in an open letter to the Patriarch (II, 67-74). The second volume also contains a list of "selected" works by Blemmydes (II, 75-76). The chapters not mentioned contain concise accounts of the information already present in the first volume. The last chapter (II, 89) is a brief edifying conclusion of the whole work.

Now we shall look at the text in more detail.

\section{Blemmydes AND THe Logos}

The reader faces the ideal of the "monk-and-scholar" throughout the whole text. Blemmydes states his principal values already in the introduction. First, he thanks God and praises His almightiness and mercy. He also states that aspiration towards God must be everyone's main concern (I, 1). Right after this passage Blemmydes puts in a meditation on the importance of the logos for rational creatures, i.e. (according to Aristotle) for humans (I, 2). Blemmydes declares his high appreciation of the logos, which for him is the most worthy feature among those inherent to human beings.

Thus, Blemmydes declares two principles underlying his Weltanschauung: on the one hand, a tireless striving towards God and on the other - towards the logoi, which are, according to Blemmydes, a

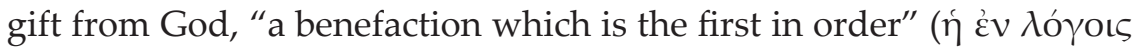

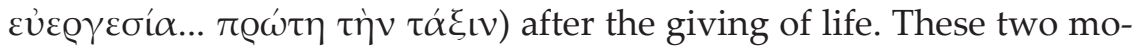
tifs - a striving toward God and high esteem of the logos - are key motifs of the work.

So as to make clear what Blemmydes means by saying "a benefaction in logoi," the notion logos should be clarified. It covers, as is well-known, a wide variety of senses. Besides the meaning "word, utterance," it denotes the "Word of God," one of the three persons of the Holy Trinity, and also "reason, understanding; immanent rationality." 20 The plural of this word, i.e. "logoi," used to point to learning, education, and sciences as a whole. ${ }^{21}$

Thus, the "benefaction in logoi" mentioned by Blemmydes should be understood as a benefaction of learning. In general, in his Autobiography Blemmydes brings in very different meanings of the notion

(20) G. W. H. Lampe, A Patristic Greek Lexicon, Oxford, 1961, p. 808.

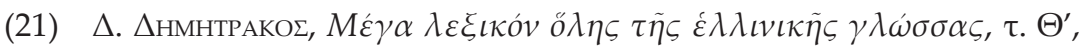
AӨ̣́vol, 1953, p. 4369. 
"logos," using it eighty two times altogether. The usage of the word with the sense "scholarship, science, knowledge" numbers twenty-one instances.

As has already been mentioned, Byzantium knew a division between "outer" and "inner" philosophy, and, as far as the former is concerned, monasticism had rather an aggressive attitude towards it. Blemmydes, however, judging by the Partial Account, does not seem to consider the division a conflict. He refers to it only twice, and the secular disciplines are rejected in neither of those cases. In the first case Blemmydes recounts his studies after coming back from Skamander, where he completed the final stage of his education:

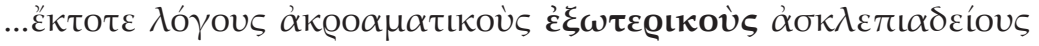

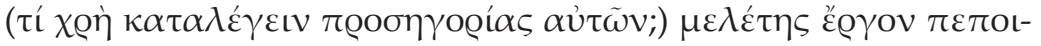

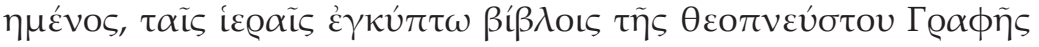
$\dot{\varepsilon} \mu \mu \mathrm{ov \omega} \tau \varepsilon \varrho 0 v$.

...since then, having made the oral, outer, Asclepiadean sciences (what is the need to list their titles?) part of my engagement, I am studying the holy books of the God-inspired Scripture more intent$\operatorname{ly}^{22}(\mathrm{I}, 10)$.

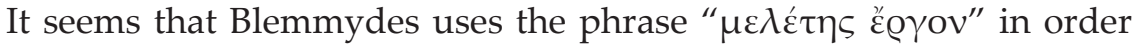
to distinguish between regular education and a period of unassisted studies, for Blemmydes never ceased to take an interest in worldly scholarship, but taught it and produced works on it. ${ }^{23}$

(22) The translation here and further on is mine.

(23) Translating this passage, Munitiz makes the following emphasis, "From that time onwards, now that I have completed my studies of technical, profane, Asclepiadean subjects ...my special efforts were devoted more steadfastly to the holy books of inspired Scripture" (Munitiz, Nikephoros Blemmydes, p. 48). However, it might be called into question whether there is such a strict distinction in the text: "having completed the studies of secular disciplines, Blemmydes began thorough studies of the Scripture." The Greek text rather implies that Blemmydes continued his engagement in secular dis-

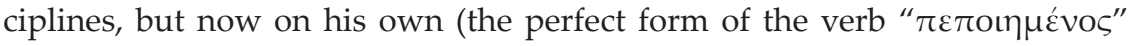
should be noted, as well as the meaning of the verb, bearing no special indication of completion). Remarkably, Hinterberger construes the passage in a third way: " ...[Blemmydes] nach Nikaia zurückkehrt. Dort studiert er weiter Medizin, vollzieht aber gleichzeitig eine Wendung zur intensiven Bibellektüre..." (Hinterberger, Autobiographische Traditionen, S. 364). Still, his interpretation agrees with the one suggested, as it also implies that Blemmydes continued his earlier studies. It should be mentioned that in the Partial Account Blemmydes uses the word " $\mu \varepsilon \lambda \varepsilon^{\varepsilon} \tau \eta^{\prime}$ twice: in the passage cited and in 
In the second case the writer mentions it in connection with one period of his life:

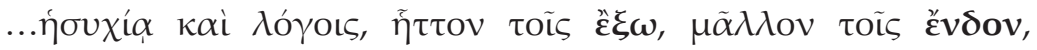

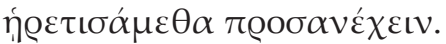

...we chose to devote ourselves to hesychia and studies, less to

the outer and more to the inner (I, 49).

Here "inner" scholarship gains the upper hand, but still - and this is revealing - the "outer" remains within the scope of Blemmydes' interests.

It is worth mentioning that even in those two rare cases when Blemmydes speaks about the division of learning into "outer" and "inner,"

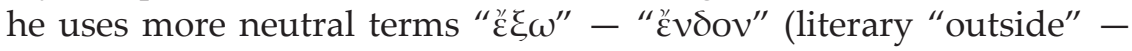
"inside") rather than the far more emotionally tinged " $\theta v ́ \mathrm{~g} \alpha \theta \varepsilon v^{\prime}$ " " $\kappa \alpha \theta^{\prime} \eta \mu \tilde{\alpha} \varsigma^{\prime \prime}$ ("outside the doors" - "ours, common for us").

Having analyzed all the instances of the word "logos" in the text, we conclude that the writer, apart from the very few cases just described, does not refer to the distinction between the two types of scholarship - he rather perceives the sphere of "logos" as a holistic one. As it will be shown further, this sphere of intellect and learning, for Blemmydes, is one of the main divine gifts. This sphere in all its integrity constitutes for him an inseparable part of monastic life.

\section{Blemmydes' Account of His Education, First Teaching Experience and Church Career}

It is characteristic of the Partial Account that, antique and medieval biographical traditions notwithstanding, the prooimion is followed not by information on his place of birth, descent, ancestry and parents, but by an account of the author's education. ${ }^{24}$ In the beginning (I, 3), Blemmydes observes that his progress in studies, even more than by assiduity and diligence, was promoted by his early acquired understanding

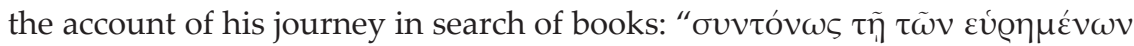

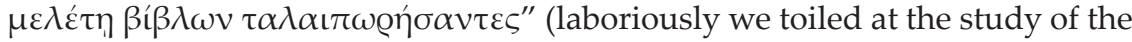
books we found) (I, 64). Notably, this last statement also implies rather an independent unassisted scholarly work, thus confirming the hypothesis about the word " $\mu \varepsilon \lambda \dot{\varepsilon} \tau \eta$ " as denoting specifically unassisted, independent scholarly engagement.

(24) The fact once more emphasizes the significance of learning (secular as well as religious, without distinction) for Blemmydes. Cf. the inclusion of logoi in the number of the most important divine gifts. 
of the true source of every knowledge, that is, God. It is from Him that Blemmydes requested knowledge and guidance - and for that reason he succeeded in learning.

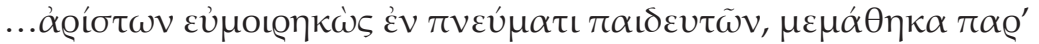

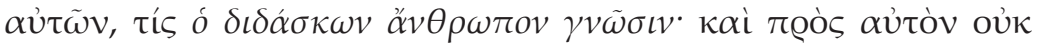

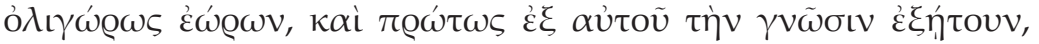

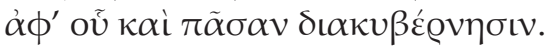

....as far as I was lucky enough to acquire the best spiritual leaders possible, I learned from them, who is He who teacheth man knowledge, ${ }^{25}$ and I did not look towards him neglectfully, and I asked for knowledge in the first place from Him, from whom [I asked] also every kind of guidance (I, 3).

It can be seen that Blemmydes speaks of God as a support in learning, secular learning included. Blemmydes connects his progress in his studies with the fact that he always realized that any knowledge, no matter whether secular or religious, comes from God.

The account of his education includes inter alia a mysterious love story, which rather vaguely tells the reader about the relations between Blemmydes, his close friend and a certain girl, who was the friend's beloved (probably a fiancée or a wife) (I, 5). The author reports that this affair had almost ruined him. The story contains quite a revealing remark:

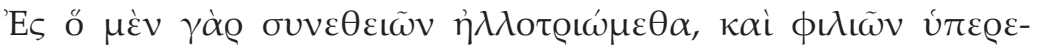

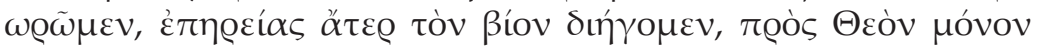

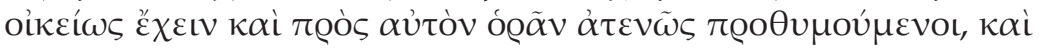

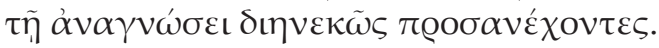

As long as we were a stranger to intimacies and disdained friendships, we led a life free from any harm, desiring to be close to God only and to look at Him intently, and constantly devoting ourselves to reading $(\mathrm{I}, 5)$.

It is the first time that we meet the ideal repeatedly reproduced by Blemmydes in his Autobiography: the ideal of combining a ceaseless striving towards God with scholarly engagement. It is such a lifestyle that Blemmydes hereafter, already recounting the monastic period of his life, will call the most appropriate for monks (II, 22). So when Blemmydes says that the monastic way of life had become habitual for him even before he took the vows, one should take into account not only the ascesis, but his studies also.

(25) Ps. 93:10 (here and further on the KJV is used). 
Continuing with the account of his education, Blemmydes speaks about an irresistible thirst for gaining more and more knowledge (the knowledge in question is actually secular knowledge) and also about all kind of hindrances, which nevertheless could not prevent him from reaching his longed-for objective $(I, 6)$. For the sake of getting to the place where a certain Prodromos lived (scholar and teacher, under whose guidance Blemmydes wanted to study) the writer undertakes a dangerous journey to the territories then subjected to the Latins. Once more it becomes clear that aspiration for all kinds of learning co-exists harmoniously with aspiration for God in Blemmydes' consciousness. More than that, they do not only co-exist, but one of them (aspiration for God) provides the satisfaction of the other (aspiration for a comprehensive education):

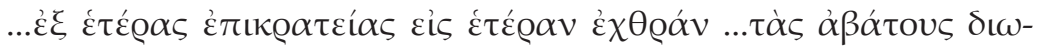

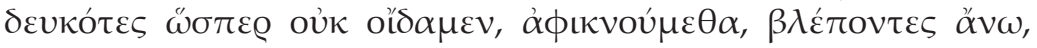

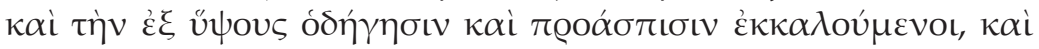

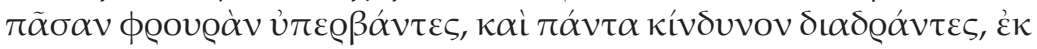

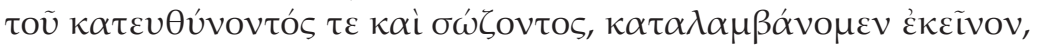

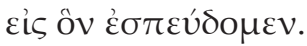

...we traveled from one realm to the other ...across the secret paths, without knowing how. Looking upwards and calling for guidance and protection from above, stepping over every hindrance and avoiding every danger, thanks to the One who directs and saves, we reached the one to whom we had strived $<$ i.e. the teacher>.

We should note the passage in which Blemmydes tells the reader about the disciplines studied at Skamander, where Prodromos lived. This passage contains among others a sui generis praise of astronomy (I, 8). Blemmydes contrasts it with astrology which he considers pseudoscience. He also dwells on the subjects astronomy deals with, as well as on its scientific potential. In conclusion Blemmydes states that astronomy:

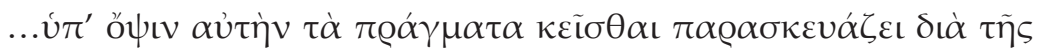

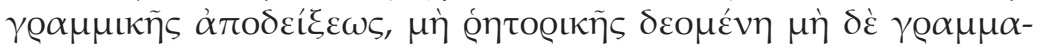
$\tau \iota \kappa \tilde{\eta} \varsigma$.

...arranges that things could be exposed before the naked eye by linear proofs, having no need either of rhetorics or grammar.

This remark might be treated as a sign of Blemmydes' interest towards clear and positive scientific proof, but this is rather guesswork, as no 
other statements of such kind can be found in the Partial Account. Still it should be taken into account when considering Blemmydes' interest towards "outer" learning.

According to Blemmydes, upon returning from Skamander he continued his studies of secular disciplines, simultaneously devoting himself to more intense studies of the Scripture (I, 10). It probably means that he commenced profound studies of theology. It would seem that Blemmydes, having mastered the secular disciplines, could have left them behind, as a preparatory stage he had already undergone, but he continues his engagement in the "outer" studies together with more thorough studies of theology. He soon entered the ranks of the church clergy, still not willing to give up his scholarly preoccupations. As it will be shown further, it is partly because of his scholarly studies that Blemmydes would leave his service as a clergyman - since this service did not leave him enough time and possibility for his studies.

Being already a clergyman, Blemmydes for the first time embarked on the field of teaching. He recounts that, after a certain church scandal came to a favorable end for Blemmydes, a lot of people formerly opposed to the writer made their peace with him and even began asking him to transmit his knowledge to them (I, 27). It is remarkable, that to describe his house in the respective period Blemmydes uses the word

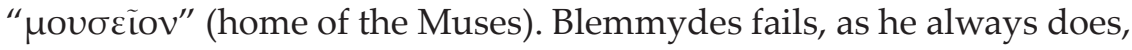
to say exactly which disciplines were discussed at the lessons he offered, mentioning only, that:

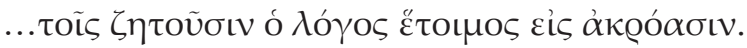

...for those seeking to hear it the logos [was] prepared.

Thus Blemmydes places the gift of logos, which comes from God, into

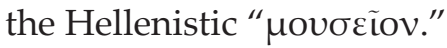

Blemmydes proved to be an efficient clergyman, but wanted, as already mentioned, to escape this duty, for it interfered "with his schol-

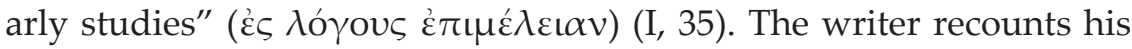
lengthy and arduous attempts to persuade the Patriarch to relieve him of his position, to "let him free for leading the habitual way of life"

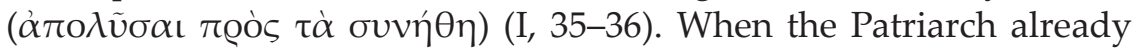
seemed to have yielded, Blemmydes went to the island of Lesbos in

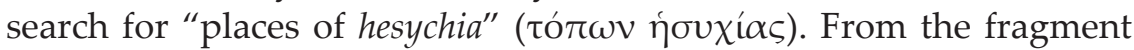
recounted it follows that the "habitual way of life," missed by Blemmydes in his position of clergyman, constitutes hesychia, that is, selfabsorbed prayer in seclusion, and scholarly studies. 
Meanwhile the Patriarch changed his mind and Blemmydes had to come back to his duties as a clergyman. But after a short time his wish was nevertheless satisfied and having left the clergy he fulfilled his long-standing intention to become a monk.

\section{MONK AND SCHOLAR}

Now we should consider the passages speaking directly or indirectly about the combination of "monastic" and "scholarly" life.

Already recounting the monastic period, Blemmydes continues to describe hesychia and scholarly studies as his favourite way of life. Such a way of life he considers the most proper for monks. Returning to his monastery after a journey to the Holy Land, Blemmydes "chose to devote" himself " to hesychia and studies, less to the outer and more to the inner" (I, 49).

One more passage containing the same formula of monastic existence should be mentioned. Before recounting the story of a conflict with the Emperor's mistress Markesina, Blemmydes says that he stayed in the monastery of St. Gregory Thaumaturgos:

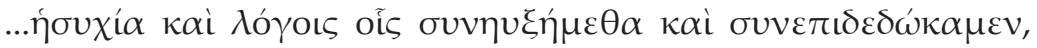

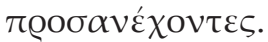

...devoting ourselves to hesychia and studies, with which [we] have been brought up and to which [we have been] completely dedicated (I, 70).

In the report about the clergyman's service (i.e. before taking the vows) one meets an indirect combination of "hesychia" and "scholarly studies" (I, 35-36). On the one hand, Blemmydes lacks time for scholarly studies, on the other - having found free time he searches for hesychia. At the same time, longing for a warrant to leave, he asks to let him lead "a habitual way of life." Thus "hesychia" and "scholarly studies" meet in the "habitual way of life."

The author's image of ideal monastic existence appears one more time in the episode about his journey to the island of Rhodes (II, 22). With outright pleasure Blemmydes recalls his sojourn in a solitary monastery, where he had at his disposal a wonderful library. There Blemmydes stayed:

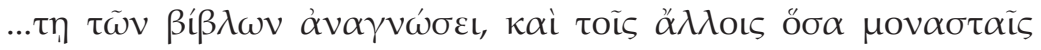

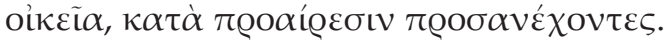

...devoting ourselves, according to our inclination, to the reading of books and to other things proper for monks. 
The word " $\alpha v \alpha ́ \gamma \nu \omega \sigma \iota \varsigma$ " occurs twice in the work. Apart from the episode just described, Blemmydes uses it in the above passage about the mysterious love affair $(I, 5)$ (see above). In this episode, similar to the above mentioned chapter I, 35, the formula "to strive towards God (hesychia being one of the main methods for this) + learning" is used in connection with Blemmydes' life while still a layman (the same can be said about the chapter II, 22). It should be thus understood: when Blemmydes later says that at the moment he took the vows the monastic way of life was not at all unknown to him (I, 37; II, 41) ${ }^{26}$ one should bear in mind not only the seclusion, the hesychia and the austere way of life, but the studies also.

Two further passages in which Blemmydes characterizes his spiritual teacher named Manasses should be mentioned:

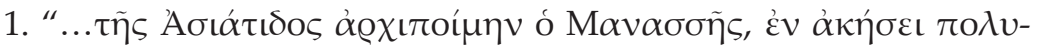

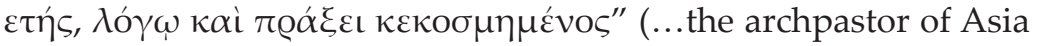
Manasses, a man of perennial ascetical experience, adorned with learning and deeds) (I, 37).

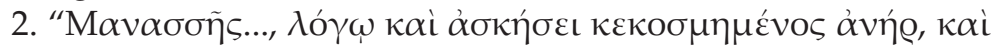

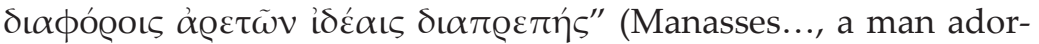
ned with learning and ascesis and distinguished by different kinds of virtues) (II, 19).

Thus Blemmydes, in describing a person whom he considers of great authority, once more correlates learning and ascesis.

$* * *$

To sum up, we managed to find seven cases in the Partial Account, in which "scholarly" and "monastic" life are directly or indirectly combined:

- Blemmydes devotes himself to "hesychia and studies" (I, 49; I, 70);

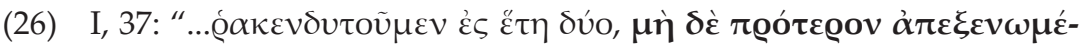

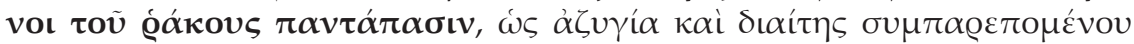

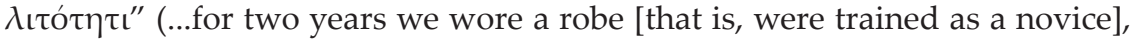
to which we had not been a complete stranger earlier, as it is attended by celibacy and simplicity of diet).

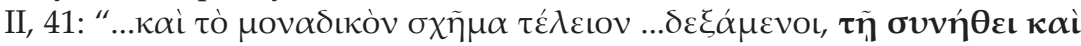

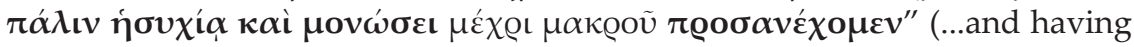
taken the full vows of the schema..., and we again engage ourselves longterm in the habitual hesychia and seclusion). 
- Blemmydes devotes himself to the "reading of books and to other things proper for monks" (II, 22);

- Blemmydes strives "to be close to God only and to look at Him intently" and at the same time constantly devotes himself to reading $(\mathrm{I}, 5)$

- the combination of "hesychia" and "studies" in Blemmydes' life becomes clear from the whole passage (I, 35-36);

- Blemmydes' spiritual teacher Manasses is characterized as "a man adorned with learning" and at the same time with "ascesis" (I, 37; II, 19).

In connection with the question about the unity of the "scholarly" and "monastic" in the Autobiography a frequent use of the verb " $\pi$ ○o$\sigma \alpha v \varepsilon ́ \chi \omega$ " (to devote oneself to something) by Blemmydes should be mentioned. The writer uses the verb five times (I, 5; I, 49; II, 22; II, 41), and all of them have already been mentioned. In the first case Blemmydes devotes himself to "reading"; in the second - to "hesychia and studies, less to the outer and more to the inner"; in the third - "to hesyshia and studies," with which he was "brought up" and to which he was "completely dedicated"; in the fourth - to the "reading of books and to other things proper for monks"; in the fifth - "to hesychia and seclusion." As can be seen, the verb is sometimes used only in combination with studies, sometimes with hesychia only, and sometimes for both of them at the same time. This fact once more illustrates that scholarly engagement and the monastic way of life, hesychia, belong to the same "field" in Blemmydes" consciousness.

\section{What Do the Descriptions of Logical-Theological Discussions Reveal?}

As it has already been mentioned, the bulk of the Partial Account's second book is formed by descriptions of public discussions Blemmydes took part in. Three of the four disputes described are merely theological: two with Latins (II, 25-40; II, 50-60) and one with Cilicians (=Armenians) (II, 61-66). The fourth discussion described is a "show" exam on logic which Blemmydes took at the court of the Nicaean Emperor (II, 8-16). Blemmydes furnishes this last description with extensive elucidation aiming at explaining certain rules for building syllogisms. The account of the scandal which aroused around Blemmydes' encomium of St. John the Theologian is to a certain extent similar in its contents and form to the descriptions of the four disputes listed (II, 67-76). 
These accounts are significant in connection with the topic our article deals with so far as they once more confirm Blemmydes' lifelong (logic, right up to old age, when the Autobiography was written) adherence to Aristotle's logic. ${ }^{27}$ Blemmydes enjoyed building syllogisms, which he could do brilliantly, and, as far as theology is concerned, applied logical methods in order to refute his opponents' inconsistent reasoning. ${ }^{28}$

\section{What Kind of Books Did Blemmydes Search for?}

The subject of the article demands that the following episode should also be taken into consideration. Blemmydes recounts his journey to the Despotate of Epirus, undertaken in order to find books not available in the Nicaean Empire. He does not specify which kind of works he searched for. Constantinides supposed that Blemmydes searched for the writings of "inner" contents, pointing at the writers' itinerary:

(27) It should be noted that some scholars consider Blemmydes a Hesychast, Gregory Palamas' forerunner: see Nicephori Blemmydae Crriculum

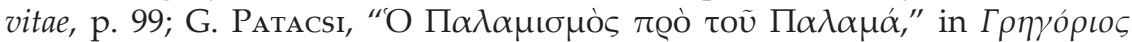

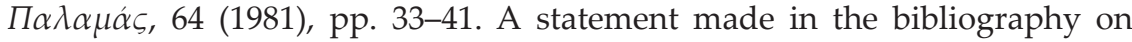
Hesychasm is revealing: "Some scholars consider him to be a Hesychast and a predecessor of Palamas... Meanwhile, Blemmydes, who conjoined Aristotelian culture with the principles of the Hesychast life, was highly valued by the anti-Palamites (Nicephorus Gregoras, Manuel Calekas)." (Исихазм: аннотированная библиография, с. 324). Thus we may affirm that Blemmydes' cultural syncretism affected also the way in which posterior theologians and philosophers perceived his activities. For Palamas' acquaintance with Blemmydes' works see I. D. Polemis, "Nikephoros Blemmydes and Gregorios Palamas," in Gregorio Palamas e oltre. Studi e documenti sulle controversie teologiche del XIV secolo bizantino, a cura di A. RIgo (Orientalia Venetiana, 16), Firenze, 2004, pp. 179-189, with references to earlier studies. On the reception of Blemmydes by both Palamites and anti-Palamites in the field of pneumatology see D. MAKAROV, "The Holy Spirit as Life and Energy. The Treatment of Athanasius Ad Serapionem I, 20-21 in the Late Thirteenth Century and its Implications for the Hesychast Controversy," Byz, 80 (2010), pp. 197-246.

(28) Blemmydes did not believe logic to be applicable to theology when affirming a certain truth about the Divine - this was to be based on the Scripture and the Church Fathers. See M. Stavrou, "De la philosophie à la théologie: l'unité du projet épistémique de Nicéphore Blemmydès (1197 - v. 1269)," in Byzantine Theologians. The Systematization of Their Own Doctrine and Their Perception of Foreign Doctrines, ed. by A. Rigo, P. Ermilov (Quaderni di Néa P $\omega \mu \eta$, 3), Roma, 2009, pp. 103-124, see 118-124. 
Larissa, Thessalonike, Athos ${ }^{29}$ but such a hypothesis raises significant doubts. Firstly, the trip was undertaken on the order of the Nicaean Emperor and its purpose was to improve the state of education and learning (in the Nicaean Empire) in general. Most probably Blemmydes was chosen for the task as a person well acquainted with the "outer" literature as well as with the "inner." Secondly, Blemmydes made for large library centers - particularly to Athos. Keeping in mind that only the library of the Great Lavra, for example, housed ca. 1000 manuscripts, ${ }^{30}$ very likely the Holy Mountain had in its possession writings of various contents. Thirdly, Blemmydes himself, as already mentioned, does not remark on the character of the books he searched for.

\section{To What Extent Do the First ANd The Second Book of The Work Differ?}

Some researchers have pointed out the heterogeneity of the two parts of the Partial Account. ${ }^{31}$ In their perspective, the first volume tells the reader rather the story of a monk, it gives more consideration to miraculous deliverances and it has stronger Christian motifs. On the contrary, the second volume is more reserved as far as miracles are concerned; it pays more attention to intellectual achievements - it is the story of a scholar, a theologian. Therefore, the volume is supplied with reports on theological and logical disputes and a list of Blemmydes' literary works.

Did Blemmydes seek to write two diverse autobiographies? We tend to consider this not to be the case. It cannot be affirmed that Blemmydes tendentiously picks out the events for each book of the Partial Account. Thus, the account of his journey in search of books, conforming rather the image of a "scholar," is put into the first book (I, 58, 63-64), while the story of his monastery's foundation, full of minute descriptions of divine help and miracles in the course of building

(29) C. N. Constantinides, Higher Education in Byzantium in the 13th and 14th Centuries (Texts and Studies on the History of Cyprus, 11), Nicosia, 1982, p. 13.

(30) A. Kazhdan, R. Browning, "Library," in Oxford Dictionary of Byzantium, p. 1224.

(31) M. Angold, "The Autobiographical Impulse at Byzantium," DOP, 52 (1998), pp. 225-257, see 247-249; Misch, Geschichte, S. 860. 
and suitable rather for a "monk's story," is found in the second book (II, 45-49). It is true that the majority of the "devil's designs" and "deliverances due to God's will" are described in the first book, but one finds them also in the second (II, 79-86). It seems to us that stories of this kind are concentrated in the first book as Blemmydes' main objective consisted of illustrating the working of divine wisdom and mercy in his own life - thus in the first place he sought to fulfill exactly this aim, using for this end traditional hagiographical tools (descriptions of miracles etc.).

The introduction to the second book, as well as that to the first, begins with a praise of God (II, 1). Later on, in the account of the writer's childhood, the following idea is accentuated: signs (during a person's childhood) indicating that one is chosen by God do not mean anything on their own account, and one does not deserve admiration for their sake. One deserves it only if in the conscious age he or she proves these signs by being worthy, by following God's will in everything - that is the only thing which deserves honor (II, 3-6). Thus Blemmydes once more returns to the motif already mentioned the necessity for striving constantly towards God, this time in the second book. The motif is also to be found further on: Blemmydes repeatedly, in a way similar to the first book, thanks God for His caring in difficult situations. Blemmydes has always had a difficult, uncompromising nature, that is why he frequently was in conflict with other people - but God has always been on his side, because Blemmydes has stood up for the truth, and the slanderers achieved nothing (II, 17-19). God supported Blemmydes during the construction of his monastery (II, 45-48); God safeguarded Blemmydes when some plotters prepared an attempt on his life (II, 80-81); after the attempt the ill-wishers decided to take advantage of some false accusations, but thanks to God's care they also led to nothing (II, 82-86). Blemmydes ends the second book exactly on this episode, making a general conclusion about God's wisdom.

Thus both the first and the second book are based on the same conjunction of the two motifs met in the introduction to the first book striving towards God and a high appreciation of scholarship. The hypothesis about Blemmydes' intentional creation of two heterogeneous autobiographies does not seem to find enough grounds in the text. The differences present are all too inessential to reflect any author's intention - most likely they emerged situationally. 


\section{Blemmydes' Attitude TOWARD "The Wisdom OF This WORLD"}

In his reflection about people favored with divine signs in their childhood Blemmydes also speaks about the miserable lot of those not proving worthy of such signs. Dwelling on the subject Blemmydes alludes to some words by the Apostle Paul, interpreting them in a remarkable way:

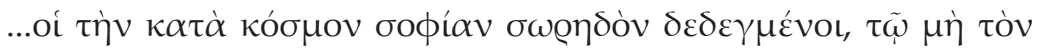

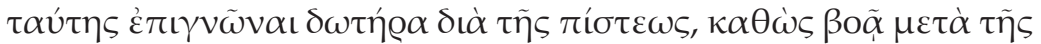
$\dot{\alpha} \lambda \eta \theta \varepsilon \dot{a} \alpha \varsigma$ ó Ȧ

...those who have received this world's wisdom in abundance,

but did not acknowledge by means of their faith the Giver of such wisdom, as rightly says the Apostle, became fools ${ }^{32} \ldots$ (II, 5).

Blemmydes thus emphasizes that those who "have received" worldly wisdom turn into fools only if they do not understand who is the giver of such wisdom (notably, in the previous phrase Blemmydes calls God "teacher" and it seems to be no allusion here). One may conclude that Blemmydes, in a revealing way, does not perceive "this world's wisdom" on its own account as something negative. The fact may be brought into connection with his aforementioned loyalty towards "outer" learning. ${ }^{33}$

\section{List OF Blemmydes' Literary WORKS}

A list of Blemmydes' "selected works," found in the second book of the Partial Account (II, 75-76), deserves some attention. The author mentions writings of philosophic-scientific character (Logic, Physics, De corpore, De anima - Blemmydes begins the list with these) as well as religious (De fide, De virtute, commentaries on certain Psalms, liturgical

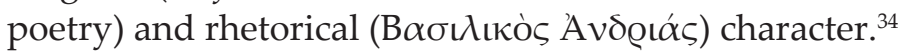

In connection with spiritual poems Blemmydes gives concise praise to God and the versatile list is concluded with a notable remark:

(32) Rom. 1:22. Cf. 1 Cor. 19:25. Munitiz fails to point out the former ref-

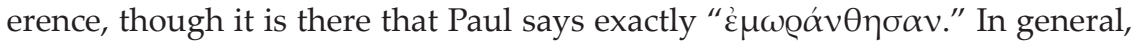
the passage from Rom. 1:21-22 seems closer to Blemmydes' passage. 124.

(33) Cf. Stavrou, “De la philosophie à la théologie," pp. 103-110, 122-

(34) I follow the classification used in Trapp, Gastgeber, Prosopographisches Lexicon, S. 2897. 


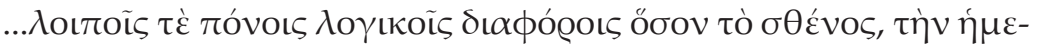
$\tau \dot{\varepsilon} \mathrm{Q} \alpha \nu \beta เ$

...to [these] and other various scholarly labours we have devoted, to the best of our ability, our life (II, 76).

So Blemmydes writes the Autobiography intending to express the idea that his life, by the grace of God, was devoted to labors in logos, which in his mind obviously does not contradict his endeavor towards God and his monastic life, which attracted him from childhood on and to which he devoted himself with an equal dedication. Those labors in logos in all probability seemed to the writer an inherent part of the path to God.

\section{Overview of the Historiography of the Problem}

Blemmydes' Autobiography has repeatedly attracted researchers' interest, and certain remarks and opinions concerning the present topic are also to be found.

The points of view about the way in which the monastic and the scholarly combined in Blemmydes consciousness and personality can be divided into two groups. The first group asserts that there existed a serious conflict in Blemmydes' inner world: between the endeavour towards Hellenistic scholarship on the one hand and towards monastic asceticism on the other. In the second case a harmonious coexistence of monastic and scholarly ideals is maintained, in other words, that Blemmydes' striving to cognize God and His Creation by means of antique scholarly legacy does not run counter, in Blemmydes' own understanding, to his striving to God by means of prayerful seclusion and studying the Scripture and the Church Fathers - on the contrary, the former rather supplements the latter.

As for the adherents of the first view, chronologically the earliest is Georg Misch, author of a multi-volume history of the autobiographical genre. ${ }^{35} \mathrm{~A}$ classical philologist as he was, Misch acted on the premise of his notion of antique ideals. This fact, as will be shown, considerably influenced his perception of Blemmydes' Autobiography.

As Misch affirms, in the Partial Account two traditions - that of the Christian "Legenden" and that of the Hellenistic "SchriftstellerAutobiographie" - struggle with each other. He believes that in the first and the second part of the writing completely different "geistige Einstellungen" prevail. In the first book the Christian monastic tradi-

(35) Misch, Geschichte; on Blemmydes, see S. 831-875, 876, and 756-757. 
tion is crucial, it is a narration in the spirit of a legend, of hagiography, abounding in miracle-descriptions, which occurred by God's mercy, and in sermon-like moralizing admonitions. In the second book, on the contrary, the spirit of Hellenistic learning wins out; its tenor is such that it evokes parallels to the creations of antique writers rather than to the Holy Scripture. ${ }^{36}$ Misch however does not fail to take into account that both heterogeneous motifs are nevertheless present in both parts of the Partial Account. But he considers the presence of "scholarly" motifs in the first part as a miscarried attempt to at last abandon the miracle-stories, "Wundergeschichten," while the presence of those particular "Wundergeschichten" and edifying passages in the second part are interpreted as another manifestation of the hagiographical virus' inexorable strength, which lets it penetrate the writings even of such learned writers as Blemmydes.

Misch insists that the distinction between the two books of the Partial Account is a crucial one. For him the two traditions, which are seen by him as respectively antique and medieval, are necessarily irreconcilable. Misch makes a significant conclusion: Blemmydes' Autobiography shows that even in such an old, deep-rooted and traditional culture as that of Byzantium (the tradition implied is obviously the Hellenistic one) once again the medieval Weltanschauung is reproduced. ${ }^{37}$

For Misch the Partial Account is an example of a certain cultural schizophrenia - he interprets the combination of the two motifs as the evidence of a complete lack of homogeneity in the work. ${ }^{38}$ Blemmydes supposedly is not himself conscious that he tries to combine something incongruous: he is an intellectual of antique culture, but he is incurably afflicted with the Middle Ages, though he does not himself realize his affliction.

Almost half a century later Michael Angold in his article, "Autobiographical Impulse in Byzantium" (1998), expresses the following opinion: Blemmydes' Autobiography testifies to its author's disillusionment with the possibility for "combining 'Hellenic' and monastic elements in his contemplative life." ${ }^{39}$ According to Angold, Blemmydes made an attempt to combine monasticism and secular learning, but

(36) Misch, Geschichte, S. 837, 867, Anm. 266, 868.

(37) Ibid., S. 875.

(38) Ibid., S. 836.

(39) Angold, "The Autobiographical Impulse," p. 249. Angold uses "Hellenic" to refer to the "outer" learning. 
at a certain moment in his life he realized it to be impossible. When writing the Autobiography, Blemmydes assigned to secular learning a merely instrumental role, a role of a long ago undergone preparatory stage for theology. Angold concurs with Misch's opinion: "Misch quite rightly detects beneath the surface of Blemmydes' autobiographies an underlying tension between two contemplative ideals: the monastic and the 'Hellenic."'

As has been shown, Misch spoke about Blemmydes as a cultural schizophrenic, who created an unhomogeneous work in which he rushes from one tradition to the other. For Misch Blemmydes (including at the time of writing the Autobiography) fully belongs to both of them, and completely accepts the one as well as the other, without being aware of the glaring, according to Misch, contradiction. Angold's view is different. He affirms that Blemmydes first consciously tried to combine the two spheres, the monastic and the "Hellenic," in his own life, but later became disillusioned with the possibility of such a combination in and of itself and reproduced this disillusionment in the Autobiography. In other words, Blemmydes consciously examined the problem of "monastic" and "scholarly" and their presumed compatibility.

Now the adherents of the second opinion, i.e. of the harmonious combination of the monastic and the scholarly, should be considered. The references will again be placed in chronological order. In the third volume of the collection Byzantine Culture (1991) two interrelated articles can be found. The first one is about the culture of the Nicaean Empire (by Pyotr Zhavoronkov). ${ }^{40}$ According to Zhavoronkov, in the thirteenth century, "the barrier which had divided secular and monastic culture until 1204, fell down. Hellenism ceased being considered to be incompatible with monastic life any longer." ${ }^{41}$ Blemmydes' worldview, as it is affirmed, followed this trend. It is mentioned that exactly after the example of Blemmydes, Maxim Planudes, being himself a hegumen, taught laymen some secular subjects. In Blemmydes' works, as Zhavoronkov noted, "one can see a rationalist trend in his thought, acknowledgement of the significance and value of all sciences and arts." ${ }^{42}$

(40) П. И. ЖАворонков, “Культура Никейской империи," in Культура Византии. ХIII - первая половина XV в., ред. Г. Г. АитАврин, Москва, 1991, c. $46-86$.

(41) Ibid., c. 85.

(42) ЖАвоРОнков, “Культура Никейской империи,” с. 57-58. 
The second related article by Vassily Bychkov is entitled, "Byzantine Esthetics in the Thirteenth-Fourteenth Centuries." ${ }^{43}$ According to Bychkov, Blemmydes was a typical representative of the movement aiming "at the removal of any and every contradiction in the spiritual culture, at uniting and harmonizing all knowledge, obtained by mankind throughout its entire history both on the paths of science and through religious experience." Bychkov noted that Blemmydes "with the same zeal wrote treatises on logics and physics, works on geography and history, writings on dogmatic theology, liturgy, asceticism, etc.," basing them, if necessary, on pagan writers (not only Aristotle, but also Plato, Porphyry and others) as well as on the Holy Scripture and the Church Fathers. ${ }^{44}$ Bychkov states that in Blemmydes' and other Byzantines' activities one meets the same tendency as "among their Italian colleagues of the proto-Renaissance orientation."

The authors of the collection thus adhered to the opinion that Blemmydes considered the monastic and the "Hellenic" scholarly culture easily compatible. It should be mentioned that the research in question was based on the works of Blemmydes as a whole, while the present analysis relies mainly on the Partial Account, using the writer's heritage in general only as a secondary and additional argument. Still the opinions reflected in the collection mentioned are important for creating a full-fledged survey on the topic dealt with.

Another supporter of the idea of a harmonious combination of the monastic and the scholarly is the last editor of the Autobiography, Joseph Munitiz. Criticizing Misch's conception in the article "Hagiographical autobiography in the Thirteenth century" (1992), Munitiz refutes the idea that there exists a conflict "between Hellenism and Byzantinism" in the two books of the Partial Account. "Both Blemmydes and Gregory of Cyprus are remarkable," as Munitiz puts it, "for their assimilation of Hellinism, so much so that in their writings $\dot{\varepsilon} \lambda \lambda \eta v \iota \kappa o ́ v$ and 'E $\lambda \lambda \alpha$ '́ $\varsigma$ have lost any pejorative connotation, and the dichotomy [found by Misch] seems a false one." 45 So Munitiz affirms that, on the one hand, the two traditions traced in the Autobiography do not confront each other, but coexist harmoniously, and, on the other hand,

(43) See В. В. Бычков, “Византийская эстетика в XIII-XV вв.,” in Культура Византии. ХIII - первал половина XV в., с. 412-447.

(44) Ibid., c. 412.

(45) J. A. Munitiz, "Hagiographical Autobiography in the Thirteenth Century," Byzantinoslavica, 53 (1991), pp. 243-249, see 249. 
that both traditions are considered by Blemmydes in a positive way and are comprehended by him as his own.

Another contribution to the topic was made by Michel Stavrou, ${ }^{46}$ in his article "De la philosophie à la théologie: l'unité du projet épistémique de Nicéphore Blemmydès (1197 - v. 1269)" (2009). Stavrou speaks about "l'unité et la cohérence de sa [Blemmydes'] démarche épistémique," which implied that God provides humankind with two types of knowledge: on the one hand, theological knowledge, received in the form of Revelation, on the other hand knowledge acquired by rational reflection and observation of the visible world, in short, scientific or philosophical knowledge (for which Hellenistic, pagan science is a source). The latter is inferior in relation to the former, because it can provide only an indirect insight into the Divine, but that does not mean that one should not engage in it: on the contrary, the second type of knowledge is quite useful, provided that it is purified of its false elements with the help of Christian Revelation. As Stavrou puts it, "le même Verbe de Dieu est à l'oeuvre dans l'intelligence spirituelle et dans l'intelligence conceptuelle, scientifique, héritée des Anciens." ${ }^{47}$ As has been mentioned above, Blemmydes rejects using the scientific method in theology, ${ }^{48}$ but being used in its proper field it contributes greatly to humankind: "Il s'agit au fond de vérifier ou de justifier par l'observation et le raisonnement scietifique les affirmations de l'Écriture sainte." 49 Stavrou, as with Bychkov, emphasizes Blemmydes' use not only of Aristotle, but also of a wide range of other pagan thinkers, ${ }^{50}$ which shows how freely the pagan heritage was used by this Christian monk, for whom it was not a problem to resort directly to these texts.

$* * *$

Having given credit to some important opinions concerning the subject of the present article let us proceed to the conclusion. Our analysis of Blemmydes' Autobiography was aimed at studying the writer's views

(46) Stavrou, "De la philosophie à la théologie." Stavrou bases his study on several works by Blemmydes.

(47) Ibid., pp. 103-104, cf. also p. 108: “...le processe de connaissance scientifique ou théologique se fait toujours par une participation à l'économie du Verbe de Dieu."

(48) Ibid., pp. 118-124.

(49) Ibid., p. 113.

(50) Ibid., pp. 108, 113. 
on the possibility of combining the monastic way of life with scholarly engagement. The results of the analysis permits one to conclude that Blemmydes considered scholarly studies part of monastic life. For him a monk spending a great deal of time in the library, reading and studying books, as well as writing his own works is something quite natural. Blemmydes does not consider scholarly engagement as a hindrance to approaching God, to spiritual work and "self-immersion" 51 - in a word, for achieving hesychia.

Apart from this, the question about the place of secular sciences in Blemmydes' value system has been posed. In other words, which disciplines, according to Blemmydes, were part of the monk's scholarly studies? The material collected contains evidence that Blemmydes, while being conscious of the division of "outer scholarship vs. inner scholarship," did not limit his studies to the "inner" disciplines only. Having at a young age mastered the secular disciplines according to the educational tradition of the time secular disciplines at a young age, Blemmydes did not cease to take an interest in them, even after taking the vows (i.e. he read the respective literature, wrote his own works, and taught them to his own students - including the students of his monastery school, i.e. novices and monks). For Blemmydes rational reflections seemed to be a help in the attempts to cognize God through Revelation, i.e. theologically, and "by grace," through prayerful work..$^{52}$

While creating the Autobiography Blemmydes does not seek to conceal his interest in the "outer" learning. Blemmydes believes the sphere of scholarship and intellect - of the logos - to be an integrity existing due to the human's ability to think and cognize. ${ }^{53}$

One cannot trace in the Partial Account itself a conception concerning the author's perception of the sciences (if this term is at all applicable to scholarship in the Middle Ages), and it is only through his other works that we get an idea about this issue: Blemmydes considers the sciences to be a tool for understanding the invisible world of the spirit.

(51) This is the word used by M.A. Polyakovskaya for describing the notion of hesychia: М. А. ПоляковскАя, “Общество, власть, интеллектуальная элита: поздняя Византия," in Историческая наука на рубеже веков, Екатеринбург, 2000, с. 87-93; repr. in ЕАDЕм, Византия, византийцьы, византинисты, Екатеринбург, 2003, с. 178-186 (182).

(52) Cf.: "Le philosoph ...est celui qui contemple la nature des étants et qui ainsi remonte aux raisons d'être ( $\lambda$ ó $\gamma \mathrm{O})$ du Créateur, et de là jusqu'au Créateur lui-même" (Stavrou, "De la philosophie à la théologie," p. 123).

Cf. ibid., p. 105. 
As far as the Autobiography is considered, it could be mentioned that just shortly before the words from the Epistle to the Romans which Blemmydes alludes to in II, 5, the text reads:

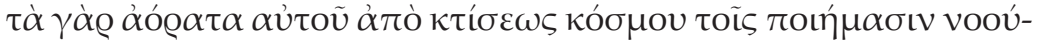

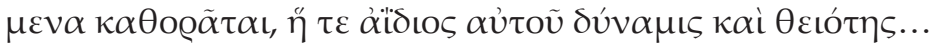

For the invisible things of Him from the creation of the world are clearly seen, being understood by the things that are made, [even] His eternal power and Godhead... ${ }^{54}$

It is revealing that Blemmydes' special attention dwelled exactly on this certain passage, well-known for its message which can be used as a justification for the sciences from a Christian point of view.

Blemmydes' scientific inquisitiveness might be seen in an appraisal to astronomy, found at the beginning of the first book of the Partial Account. In this appraisal the author admires the possibilities this discipline provides for exploring the phenomena of the surrounding world and for building proof - "linear" rather than rhetorical, that means scientific proof by diagrams and graphics. The versatility of the preserved works by Blemmydes is also a proof of his scientific inquisitiveness.

The question about Blemmydes either being an exception from general rules or a representative of a certain trend in Byzantine monasticism has also been posed. We have access to the fact that Blemmydes for some time studied under the guidance of a certain Prodromos, who supposedly was hegumen of a monastery and taught, as we know for sure, secular sciences there. Later Blemmydes reproduced this scheme in his own monastery. Such a consideration suggests a certain continuity of the principle of "intellectual monasticism," but this is not more than a hypothesis.

Nevertheless, the assertion about Byzantine monasticism's hostility towards the so-called "Christian Humanism" is not so far from the truth. Eastern monasticism has always considered ascesis and prayer the most important, if not the only possible way of approaching the divine. All the same, a search for some traces of Byzantine "intellectual monasticism" may be fruitful; the present article is an illustration of this.

Nikephoros Blemmydes' personality and activity, almost completely concurring with the crisis period of Latin domination in Constantinople, suggests that there exists a strong connection between monasti-

(54) Rom. 1:20. 
cism's assumption of the "intellectual mission" and the collapse of civil structures and secular education. The phenomenon is most obvious in the case of post-Roman Western Europe - and Byzantium in the thirteenth century could probably have followed a similar path, if it had not been for the temporary revival after the re-capture of the capital in 1261 . This is a general observation requiring further examination here it should only be mentioned that Nikephoros Blemmydes is a figure important for this topic.

\section{SUMMARY}

The article considers the problem of monastic and scholarly ideals in the world view of the $13^{\text {th }}$ c. Byzantine theologian Nikephoros Blemmydes as reflected in his so-called Autobiography. It is maintained that Blemmydes managed to combine both kinds of ideals throughout his life without feeling any kind of contradiction in such a position - on the contrary, both consisted for him an indivisible unity. The statement is based on the close reading of the Autobiography's text, which is also put in the context of Blemmydes' biography and writing activity as a whole. Two trends in the investigation of the question are detected and discussed: maintaining a conflict, outer or inner, in Blemmydes' views (Misch, Angold), or considering them quite harmonious (Munitiz, Zhavoronkov, Bychkov, Stavrou). Thus Blemmydes' self-identification as a scholar-monk is asserted, as well as his belief that such a combination is in fact natural for monastic life in general. 